\title{
Root Pruning and Auxin Alter Root Morphology of Hickories
}

\author{
Brandon M. Miller ${ }^{1}$ and William R. Graves \\ Department of Horticulture, Iowa State University, Horticulture Hall, 2206 \\ Osborn Drive, Ames, IA 50011-4009
}

Additional index words. auxin, hickory, morphology, root prune, taproot

\begin{abstract}
A reputation for coarse root systems with dominant taproots, and for slow shoot development among seedlings, limits use of hickory species (Carya Nutt.) that could increase diversity in managed landscapes. We examined effects of root pruning and application of auxin on root and shoot development of seedlings of several species of hickory. Our hypothesis was that pruning the radicle shortly after seed germination and subsequent treatment with auxin would increase root branching without curtailing development of the shoot. Germinated seeds of Carya aquatica (F. Michx.) Nutt., Carya cordiformis (Wangenh.) K. Koch, Carya laciniosa (F. Michx.) Loudon, Carya ovata (Mill.) K. Koch, and Carya tomentosa (Lam.) Nutt. were treated by removing two-thirds of the length of the radicle with and without immediate application of $3000 \mathrm{mg} \cdot \mathrm{L}^{-1}$ indole-3butyric acid (IBA) via Hormex rooting powder \#3 to the remaining one-third of radicle. Neither treatment altered stem height, stem caliper, or root dry weight. After 75 days, root-pruned seedlings of Carya ovata without auxin had $42 \%$ fewer fibrous first-order lateral roots than did unpruned controls. Root pruning plus auxin led to a $79 \%$ increase in the number of fibrous first-order lateral roots of $C$. laciniosa and an $\approx 50 \%$ increase in the shoot dry weight of $C$. aquatica. Both root pruning and root pruning plus auxin evoked formation of taproot branches for all species. Because species differed in responses of root and shoot systems to root pruning with and without auxin, the practice should be implemented cautiously based on the species.
\end{abstract}

Hickories are deciduous woody perennials of the genus Carya (Elias, 1980). Most are stately trees of medium to large size, exhibiting grand ornamental features that justify their use as shade trees. All are recognized for their large, protuberant taproots (Thompson and Grauke, 1991). The characteristic taproot and minimal root branching of the hickories are often associated by nursery growers with the slow initial development of seedlings and a resistance to successful transplanting. For example, Dirr (2009) attributed the $60 \%$ mortality of transplanted seedling liners of Carya ovata to their carrot-like taproot. Because of this issue, the extent of production and horticultural application of hickories in the nursery trade remain minimal.

Harris et al. (2001) suggested that root pruning of Quercus rubra L. (red oak), which presumably results in a more branched or fibrous root system, may facilitate transplanting and container production. Root pruning can affect the number of lateral roots and subsequently the likelihood of transplant success (Schultz and Thompson, 1990). Some evidence suggests that increasing the number of lateral roots by removing parts of the taproot can result in an increase in tree height (Woodroof and Woodroof, 1934). Zhang et al. (2015) observed no difference

Received for publication 7 Mar. 2019. Accepted for publication 10 June 2019.

${ }^{1}$ Corresponding author. E-mail: bmm244@ cornell.edu. in the height or caliper in seedlings of Carya illinoinensis (Wangenh.) K. Koch after exposure to root-pruning treatments; however, they found root pruning promotes the growth of first-order lateral roots. The type and size of lateral roots may also govern seedling establishment after transplanting. Coarse lateral roots arising from pruning sites as a result of undercutting in the field, sometimes referred to as wound roots or taproot branches, are considered important for posttransplant establishment and survival (Schultz and Thompson, 1990). Initiation of lateral roots is stimulated by auxin and other growth regulators (Esau, 1965). Plant growth regulators have been used with other species that perform poorly after transplanting, such as Q. rubra and Liriodendron tulipifera (L.). Crunkilton et al. (1994) exposed the roots of seedlings of $Q$. rubra to IBA by incorporating granules of IBA-infused clay into the growing medium and described increases in root length, shoot diameter, shoot dry weight, and leaf area. Carlson (1974) observed an increase in the number of lateral roots by 24 times in seedlings of $Q$. rubra after exposure to indole-3-acetic acid (IAA) solution. Kelly and Moser (1983) found root regeneration could be enhanced by soaking the roots of seedlings of $L$. tulipifera in solutions of IBA before transplanting.

Little information exists on the morphology of seedlings of Carya spp., other than $C$. illinoinensis, and on effects of root pruning on seedling shoot and root morphology of hickories. Often, investigations on the effects of root pruning with coarsely rooted species focus on seedlings past their first year of growth (McCraw and Smith, 1998) without considering modification of seedling root morphology through root pruning shortly after seed germination. Furthermore, there has not been any investigation of the effects IBA may have on lateral root branching of any Carya species. Our objectives were to quantify the number of fibrous first-order lateral roots, branching of the taproot, and shoot development of five species of hickory, as well as to determine the effects of root pruning and auxin on root morphology and shoot growth.

\section{Materials and Methods}

Seeds were collected in 2015 from multiple individuals of each species indigenous near Franklin, VA $(C$. aquatica and $C$. tomentosa), Chariton, IA ( $C$. cordiformis and $C$. laciniosa), and Ames, IA (C. ovata). Seeds were deemed putatively viable after sinking in tap water (Vandevender, 2014), surface sterilized with a $70 \%$ ethanol solution, and mixed with moist, long-fiber sphagnum moss in plastic bags. Hickories exhibit embryo dormancy (Dirr, 2009) and were stratified in a dark cooler for $120 \mathrm{~d}$ at $4{ }^{\circ} \mathrm{C}$.

After stratification, 50 seeds of each species were removed and sown $\approx 5 \mathrm{~cm}$ deep (Wood, 2003) into rectangular trays that measured $13 \mathrm{~cm}$ long $\times 40 \mathrm{~cm}$ wide $\times 12$ $\mathrm{cm}$ tall filled with Sunshine LC1 Professional Growing Mix (Sungro Horticulture; Agawam, MA). The seeds were allowed to germinate under normal conditions in a greenhouse in Ames, IA. Treatments were imposed in a staggered pattern to accommodate asynchronous germination beginning 13 Apr. 2016 and ending 11 May 2016. Each day, seedlings were inspected for emergence. Treatments were imposed when three seedlings of a species emerged with similar epicotyl heights (within $2 \mathrm{~cm}$ of one another). Seedlings were grouped, with one seedling treated as a control (no taproot pruning), the second treated with severe taproot pruning (removal of two-thirds of the taproot), and the third treated with severe taproot pruning plus the application of $3000 \mathrm{mg} \cdot \mathrm{L}^{-1}$ Indole-3butyric-acid via Hormex \#3 (Maia Products, Inc., Westlake Village, CA). Auxin was applied by coating the pruning wound with Hormex \#3. A talc-based auxin was chosen instead of a liquid to avoid adverse effects of direct contact of an alcohol-based solution to the taproot. The study comprised 12-singleplant replicates per treatment and species $(\mathrm{N}=180)$.

The taproot of each seedling was pruned using a sterile razorblade. The range of taproot lengths (in $\mathrm{cm}$ ) at the time of treatment initiation varied between species: $C$. aquatica (6-12), C. cordiformis (11-24), C. laciniosa (6-14), C. ovata (3-16), C. tomentosa (7-13). After treatments, the seedlings were potted singly into nursery containers that measured $16.5 \mathrm{~cm}$ in diameter and 17.8 $\mathrm{cm}$ deep, which were filled with Sunshine LC1 Professional Growing Mix (Sungro 
Table 1. Significance of species and treatment main effects and their interactions on six responses to pruning and auxin treatments applied to taxa of Carya.

\begin{tabular}{llcrrr}
\hline Response & \multicolumn{1}{c}{ Effects $^{\mathrm{z}}$} & df & df den. $^{\mathrm{y}}$ & F ratio & $P$ value $^{\mathrm{x}}$ \\
\hline Shoot dry weight & Species & 4 & 116.5 & 72.31 & $<0.0001$ \\
& Treatment & 2 & 126.9 & 1.12 & 0.33 \\
& Species*Treatment & 8 & 127.0 & 2.32 & 0.0237 \\
Root dry weight & Species & 4 & 118.9 & 48.02 & $<0.0001$ \\
& Treatment & 2 & 121.2 & 9.98 & $<0.0001$ \\
& Species*Treatment & 8 & 121.2 & 1.35 & 0.2238 \\
Count of taproot branches & Species & 4 & 86.7 & 7.75 & $<0.0001$ \\
& Treatment & 2 & 120.1 & 156.01 & $<0.0001$ \\
& Species*Treatment & 8 & 120.1 & 6.17 & $<0.0001$ \\
Stem height & Species & 4 & 97.3 & 151.60 & $<0.0001$ \\
& Treatment & 2 & 124.9 & 1.96 & 0.1458 \\
& Species*Treatment & 8 & 124.9 & 0.99 & 0.4494 \\
Stem caliper & Species & 4 & 110.4 & 50.82 & $<0.0001$ \\
& Treatment & 2 & 124.5 & 1.83 & 0.164 \\
Count of fibrous first-order lateral roots & Species*Treatment & 8 & 124.5 & 0.65 & 0.7352 \\
& Species & 4 & 109.6 & 12.43 & $<0.0001$ \\
& Treatment & 2 & 125.9 & 17.36 & $<0.0001$ \\
& Species*Treatment & 8 & 125.9 & 2.52 & 0.0142 \\
\hline
\end{tabular}

${ }^{\mathrm{z}}$ Main effects and interactions.

${ }^{\mathrm{y}}$ Denominator $\mathrm{df}$ for the effect test.

${ }^{\mathrm{x}}$ Significance at $P \leq 0.05$.

Table 2. Shoot dry weight, root dry weight, and count of taproot branches of five species of hickory by treatment. Values are means of 12 replicate seedlings grown for $75 \mathrm{~d}$ in a greenhouse in Ames, IA. Shoot dry weight and root dry weight data were transformed to square roots for analysis; nontransformed values are presented.

\begin{tabular}{llccc}
\hline Taxon & \multicolumn{1}{c}{ Treatment } & Shoot dry wt $(\mathrm{g})^{\mathrm{z}}$ & Root dry wt $(\mathrm{g})$ Taproot branches $^{\mathrm{y}}$ \\
\hline C. aquatica & Control & $3.6 \mathrm{bc}$ & $4.9 \mathrm{ab}$ & $0.3 \mathrm{fg}$ \\
& Root prune $^{\mathrm{x}}$ & $4.7 \mathrm{ab}$ & $5.0 \mathrm{ab}$ & $1.9 \mathrm{def}$ \\
& Root prune \& auxin $^{\mathrm{w}}$ & $5.3 \mathrm{a}$ & $5.2 \mathrm{a}$ & $2.5 \mathrm{cde}$ \\
C. cordiformis & Control & $0.9 \mathrm{e}$ & $2.4 \mathrm{~cd}$ & $0.3 \mathrm{~g}$ \\
& Root prune & $1.1 \mathrm{de}$ & $1.7 \mathrm{~cd}$ & $2.4 \mathrm{cde}$ \\
& Root prune \& auxin & $0.8 \mathrm{e}$ & $1.4 \mathrm{~cd}$ & $3.0 \mathrm{cde}$ \\
C. laciniosa & Control & $3.9 \mathrm{ab}$ & $6.9 \mathrm{a}$ & $0.0 \mathrm{~g}$ \\
& Root prune & $4.0 \mathrm{ab}$ & $5.1 \mathrm{ab}$ & $4.0 \mathrm{abc}$ \\
& Root prune \& auxin & $3.6 \mathrm{abc}$ & $5.0 \mathrm{ab}$ & $5.2 \mathrm{a}$ \\
C. ovata & Control & $1.1 \mathrm{de}$ & $2.3 \mathrm{~cd}$ & $0.2 \mathrm{~g}$ \\
& Root prune & $0.8 \mathrm{e}$ & $1.2 \mathrm{~d}$ & $1.6 \mathrm{efg}$ \\
& Root prune \& auxin & $1.0 \mathrm{de}$ & $1.3 \mathrm{~d}$ & $5.1 \mathrm{ab}$ \\
& Control & $1.7 \mathrm{de}$ & $3.1 \mathrm{bc}$ & $0.2 \mathrm{~g}$ \\
& Root prune & $1.4 \mathrm{de}$ & $2.1 \mathrm{~cd}$ & $2.8 \mathrm{cde}$ \\
& Root prune \& auxin & $2.0 \mathrm{~cd}$ & $2.3 \mathrm{~cd}$ & $3.5 \mathrm{bcd}$ \\
\hline
\end{tabular}

${ }^{\mathrm{z}}$ Means (within column) with same letter are not significantly different according to Tukey's honestly significant difference test $(P \leq 0.05)$.

${ }^{\mathrm{y}}$ Mean number of primary branches from the taproot across the treatment for a species.

${ }^{\mathrm{x}}$ Two-thirds of the total length of the radicle was pruned.

${ }^{\mathrm{w}}$ Two-thirds of the total length of the radicle was pruned with the subsequent application of auxin to the wound.

Horticulture; Agawam, MA). Plants were randomly assigned to a location within a completely randomized block design on a greenhouse bench, where four Hobo pendant sensors (Onset Computer Corporation, Bourne, MA) logged irradiance and temperature every $15 \mathrm{~min}$. Mean irradiance was $25.5 \pm 7.9 \mathrm{~mol} \cdot \mathrm{m}^{-2} \cdot \mathrm{s}^{-1}$. Mean temperature was $26.8{ }^{\circ} \mathrm{C}$ with a range of 15 to $54.8{ }^{\circ} \mathrm{C}$. Relative humidity, monitored at 10 -min intervals with an Argus Titan II control system humidistat (Argus Control Systems Ltd., Surrey, British Columbia, Canada), averaged $54.4 \%$ and ranged from $13.6 \%$ to $85.2 \%$. Plants were irrigated twice weekly, once with tap water $(\mathrm{pH}=9)$ and once with a mix of water-soluble fertilizers with concentrations of $50 \mathrm{mg} \cdot \mathrm{L}^{-1} \mathrm{~N}$ provided from $21 \mathrm{~N}-2.2 \mathrm{P}$ $16.6 \mathrm{~K}$ and $100 \mathrm{mg} \cdot \mathrm{L}^{-1} \mathrm{~N}$ provided from $15 \mathrm{~N}-$ 2.2P-12.5K (ICL Specialty Fertilizers, Dublin,
$\mathrm{OH})$. The blend $(\mathrm{pH}=6.5)$ supplied the following $\left(\mathrm{mg} \cdot \mathrm{L}^{-1}\right)$ : 150 nitrogen, 8.6 phosphorus, 92.2 potassium, 33.3 calcium, 13.3 magnesium, 0.75 iron, 0.4 manganese, 0.4 zinc, 0.2 copper, 0.2 boron, and 0.5 molybdenum. The experiment spanned from 13 Apr. 2016 to 25 July 2016. Final growth data were collected by destructively harvesting the plants in a staggered pattern on the 75th day of treatments. Shoot and root dry weight, number of taproot branches, stem height, stem caliper, and number of fibrous first-order lateral roots were quantified. Data were collected by removal of the containers and placement of plants in large buckets filled with tap water. Once saturated, soilless mix was carefully removed from the roots by gently massaging the root mass under water followed by a final rinse with tap water. The number of taproot branches (coarse roots $>2 \mathrm{~mm}$ diameter arising from prun- ing wound) and fibrous first-order lateral roots (secondary roots $<2 \mathrm{~mm}$ diameter) were counted by hand. Stem height was measured from the apical meristem to the cotyledon scar. Stem caliper was measured $2.5 \mathrm{~cm}$ above the cotyledon scar. Shoots and roots were separated by cutting through the stem tissue at the cotyledon scar with hand pruners. Shoot and root dry weights were calculated after oven drying for $72 \mathrm{~h}$. Each of the six growth data variables was analyzed by analysis of variance with a block effect and fixed effects of species, treatment, and the interaction of species and treatment, as well as a random effect of group nested within block. Post hoc comparisons were performed using Tukey's honestly significant difference test. Stem caliper, stem height, number of fibrous first-order lateral roots, shoot dry weight, and root dry weight data were square-root transformed to meet the assumptions of the model. All data were analyzed with JMP Pro 14 software (JMP Version 14; SAS Institute, Inc., Cary, NC).

\section{Results}

Interaction effects between species and treatment were found for shoot dry weight and the counts of taproot branches and firstorder lateral roots (Table 1). Among the responses for which an interaction effect was not evident, all (root dry weight, stem height, and stem caliper) were affected by the main effect of species, whereas only root dry weight was affected by treatment (Table 1).

Shoot dry weight of $C$. aquatica treated with root pruning plus auxin exhibited an $\approx 50 \%$ increase in shoot dry weight compared with the control (Table 2). Root pruning and root pruning plus auxin did not affect stem height (Fig. 1) or stem caliper (Fig. 1). Root pruning and root pruning plus auxin had variable effects on root morphology. Root pruning plus auxin led to $\mathrm{a} \approx 79 \%$ increase in the number of fibrous first-order lateral roots of $C$. laciniosa compared with untreated controls (Fig. 1). When compared with root-pruned plants, seedlings of C. ovata treated with root pruning plus auxin showed an increase in the number of fibrous first-order lateral roots of $\approx 152 \%$ (Fig. 1).

The morphology of coarse roots was affected by root pruning and by root pruning plus auxin (Table 2). Taproots of all seedlings in the two pruning treatments branched, whereas branching was minimal among most unpruned seedlings (Table 2). Seedlings of $C$. ovata with root wounds exposed to auxin formed more root branches than did seedlings not exposed to auxin (Table 2). All root branches formed at the site of the pruning wound of the radicle. The branches were coarse, $>2 \mathrm{~mm}$ in diameter, and similar to the thickness of the original taproot (Fig. 2).

\section{Discussion}

Conflicting evidence dominates the literature regarding the effects of root pruning of woody perennials. Generalized statements may be inaccurate because of the multiple 


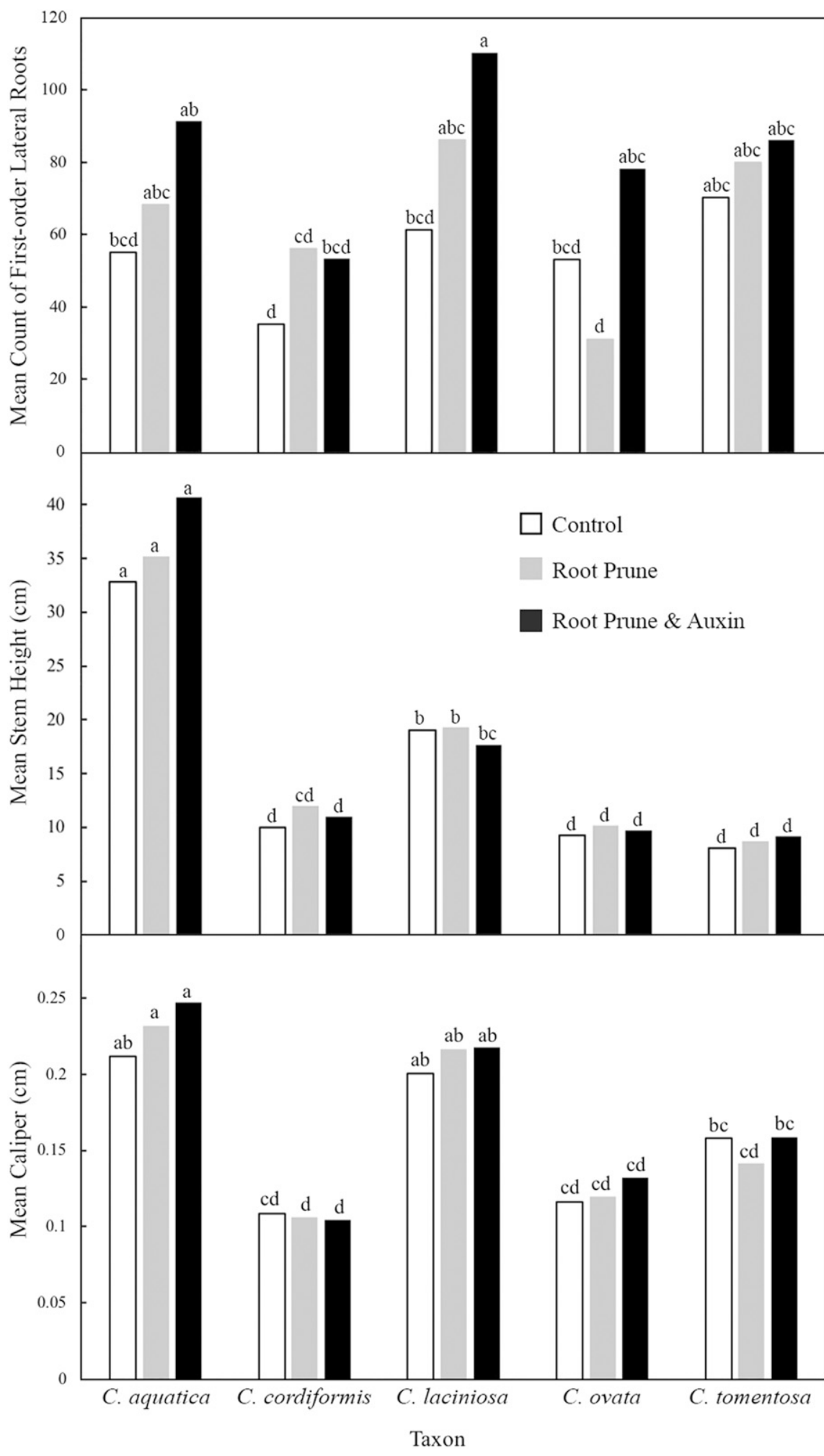

Fig. 1. Mean stem height, stem caliper, and count of first-order lateral roots $(<2 \mathrm{~mm}$ diameter $)$ of five hickory species by treatment. Means (across species and treatment per response) with same letter are not different according to Tukey's honestly significant difference test $(P \leq 0.05)$. Although data were transformed to square roots for analysis, nontransformed values are presented.

factors that may affect responses. Variable growth responses may result based on the timing and severity of root pruning as well as the taxa involved (Gilman, 1990). Previous researchers have investigated effects of root pruning on seedlings and transplants of $C$. illinoinensis. Ouedraogo et al. (2018) found pruning of circling taproots of containergrown $C$. illinoinensis did not influence stem caliper or shoot growth 4 years after transplanting. Albeit the plants were younger and evaluated within 1 year, the results of our experiment with five different species of Carya corroborate this theme. Zhang et al. (2015) observed both increases and decreases in the shoot dry weight of seedlings of $C$. illinoinensis that were root-pruned at five stages of radicle and hypocotyl length shortly after germination. Wood (1996) found root pruning did not affect the shoot dry weight of 3-year-old transplants of $C$. illinoinensis. In our study, root pruning alone did not affect shoot dry weight (Table 2) of any of the five species. Root pruning and auxin, however, increased the shoot dry weight of $C$. aquatica but had no effect on the other four species. This increase in the shoot dry weight of $C$. aquatica (Table 2) aligns with the findings of Crunkilton et al. (1994), who observed increases in the shoot dry weight of seedlings of Q. rubra grown in potting medium infused with IBA. Similar to the findings of Wood (1996), who studied 3-year-old transplants of C. illinoinensis, and of Harris et al. (2001), who worked with seedlings of Quercus palustris Münchh (pin oak), we observed the formation of taproot branches at the site of the pruning wound. The number of taproot branches varied among species and between the two pruning treatments. Both C. laciniosa and $C$. ovata responded to root pruning plus auxin with more fibrous lateral roots when compared with the control and root-pruned treatment, respectively. Likewise, Prager and Lumis (1983) observed more lateral roots on Acer saccharum Marsh. (sugar maple) and $Q$. rubra after treating roots with $3000 \mathrm{mg} \cdot \mathrm{L}^{-1}$ IBA.

Although the taxa we studied are from the same genus, our results demonstrate species-specific growth responses to both root pruning and root pruning plus auxin shortly after germination. Our study provides several new observations related to the development of hickories and thereby illustrates that reports on pecan should not be generalized to its congeners. Furthermore, this research may aid producers of hickories because our findings suggest that root pruning plus auxin can improve the shoot (Table 2) and the root (Fig. 1) systems of some hickories.

Nursery growers and urban foresters throughout the United States have shown a growing interest in producing and planting hickories in managed landscapes. In the southeastern states, C. aquatica has been suggested for use in urban landscapes because of its potential for tolerance to variable soil-moisture extremes and claims of rapid growth relative to its congeners. Seedlings of C. aquatica included in this study exhibited unique growth responses conducive to horticultural production. Specifically, untreated seedlings of $C$. aquatica were approximately three times taller than the combined average height of untreated seedlings of its congeners. Furthermore, root pruning and auxin resulted in a $50 \%$ increase in shoot dry weight, suggesting growth-manipulation techniques can enhance plant growth in the nursery. Our findings, along with the potential for tolerance of urban environmental conditions, 


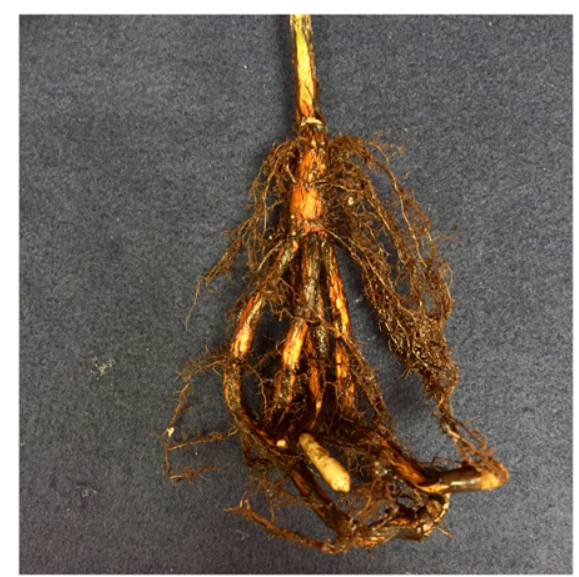

Fig. 2. Root morphology of a seedling of Carya laciniosa treated with root pruning plus auxin. Fibrous first-order lateral roots $(<2 \mathrm{~mm}$ diameter) are present throughout and are observed emerging from the coarse roots (the remnant of the original taproot and the taproot branches). Branching of the taproot is shown, with four taproot branches emerging from the site where pruning occurred.

support efforts of the green industry to expand the utilization of C. aquatica in urban settings.

Decisions regarding root pruning of coarsely rooted plants should likely account for variation among taxa. In addition, growers should consider the use of IBA, which may positively alter the morphology of the roots and the development of the shoot when compared with traditional root pruning alone. Further investigation of coarsely rooted taxa belonging to the same genus may corroborate the theme we observed with Carya and may enable the production of select taxa in nurseries.

\section{Literature Cited}

Carlson, W.C. 1974. Root initiation induced by root pruning in northern red oak. Forest Res. Rev., Ohio Agr. Res. Dev. Ctr., Wooster.

Crunkilton, D.D., H.E. Garrett, and S.G. Pallardy. 1994. Growth and ectomycorrhizal development of northern red oak seedlings treated with IBA. HortScience 29:771-773.

Dirr, M. 2009. Manual of woody landscape plants: Their identification, ornamental characteristics, culture, propagation and uses. 6th ed. Stipes, Pub., Champaign, IL.

Elias, T.S. 1980. The complete trees of North America: Field guide and natural history. Van Nostrand Reinhold Company \& Times Mirror Magazines Inc., New York, NY.

Esau, K. 1965. Plant anatomy. 2nd ed. John Wiley \& Sons, New York, NY.

Gilman, E.F. 1990. Tree root growth and development. II. Response to culture, management and planting. J. Environ. Hort. 8:220-227.

Harris, J.R., A. Niemiera, J. Fanelli, and R. Wright. 2001. Root pruning pin oak liners affects growth and root morphology. HortTechnology 11:49-52.

Kelly, R.J. and B.C. Moser. 1983. Root regeneration of Liriodendron tulipifera in response to auxin, stem pruning, and environmental conditions. J. Amer. Soc. Hort. Sci. 108:10851090.
McCraw, B.D. and M.W. Smith. 1998. Root pruning and soil type affect pecan root regeneration. HortTechnology 8:573-575.

Ouedraogo, F.B., B.W. Brorsen, J.T. Biermacher, and C.T. Rohla. 2018. Alternate methods of transplanting pecan trees. HortTechnology 28:795-798.

Prager, C.M. and G.P. Lumis. 1983. IBA and some IBA-synergist increases of root regeneration of landscape-size and seedling trees. J. Arboric. 9:117-123.

Schultz, R.C. and J.R. Thompson. 1990. Nursery practices that improve hardwood seedling root morphology. Tree Planter's Notes 41(3):2132.

Thompson, T.E. and L.J. Grauke. 1991. Pecans and other hickories (Carya), p. 839-904. In: J.N. Moore and J.R. Ballington (eds.). Genetic resources of temperate fruit and nut crops. Int. Soc. Hort. Sci, Wageningen, The Netherlands.

Vandevender, J.C. 2014. Propagation protocol for production of field-grown Carya ovata (Mill.) K. Koch plants (1-0). 22 Feb. 2016. <https://www.nrcs. usda.gov/Internet/FSE_PLANTMATERIALS/ publications/wvpmcot12151.pdf $>$.

Wood, B.W. 1996. Establishing pecan transplants. HortTechnology 6:276-279.

Wood, B.W. 2003. Propagation of major tree nut crops cultivated in North America, p. 21-53. In: D. Fulbright (ed.). Nut tree culture in North America. Vol. 1. Northern Nut Growers Assoc., Inc. Pub., Northfield, OH.

Woodroof, J.G. and N.C. Woodroof. 1934. Pecan root growth and development. J. Agr. Res. 49:511-530.

Zhang, R., F.R. Peng, P. Yan, F. Cao, Z.Z. Liu, D.L. Le, and P.P. Tan. 2015. Effects of root pruning on germinated pecan seedlings. HortScience 50:1549-1552. 